\title{
白子川流域の水路跡と管理用通路及び
}

\section{隣接する土地を活用した雨水流出抑制による治水効果の試算 \\ A TEST CALCULATION OF FLOOD CONTROL EFFECT BY THE OUTFLOW CONTROL OF RAINWATER FROM WATERWAY TRAILS, RIVER MAINTENANCE PASSAGES AND ADJOINING LANDS IN THE SHIRAKO RIVER BASIN}

\author{
市川尚紀*，中込 英 樹**，鈴木信 宏*** \\ Takanori ICHIKAWA, Hideki NAKAGOME and Nobuhiro SUZUKI
}

\begin{abstract}
Collecting rainwater in a river basin and slow flowing out can prevent urban river flood and create a pleasant walkway along a stream. We surveyed the location and area of waterway trails, river maintenance passages, and adjoining public and private open lands for rainwater in the Shirako River Basin. And we did a test calculation of flood control effect by outflow control of rainwater and measured collecting amount of rainwater and section sizes of the waterways.

We also examined that the waterway can be a daily walkway along a rainwater stream. In heavy rain, the waterway is made such as to become a wider and deeper stream which controls river flood. In addition we examined that the present river which was constructed for a $30 \mathrm{~mm} / \mathrm{h}$ rain fall has enough section size for $50 \mathrm{~mm} / \mathrm{h}$ rain fall because of the controling devices for outflow rainwater at the adjoining open lands, waterway trails and river maintenance passages.
\end{abstract}

Keywords : river basin, rainwater, waterway trail, river maintenance passage, adjoining land, control of outflow 流域、雨水、水路跡、管理用通路、隣接土地、流出抑制

1. 序

\section{1 はじめに}

対象とした白子川は、練馬区東大泉の大泉井頭公園付近の 涌水を起点とし、和光市と板橋区を流れ新河岸川に合流する 一級河川である。その全長は約 $10 \mathrm{~km}$ 、流域面積は約 $25 \mathrm{k} \mathrm{m}^{2}$ で ある。かつての白子川流域にあった多くの水田や用水路は都 市化とともに宅地化され、流域に降った雨水は地面に浸透せ ずに川へ一気に流出する都市洪水が起きるようになった。そ して、支流は枮渴し用水路は不要となって、蓋がかけられた り埋め立てられて水路跡洁1となった（写真１と２）。このよう な水路跡がある川近傍の低地は地下水が高く、雨水を浸透さ せるよりも貯留する方が適している。また、水路跡の延長は 非常に長く、自然な地形に沿っており、大規模な造成を施さ

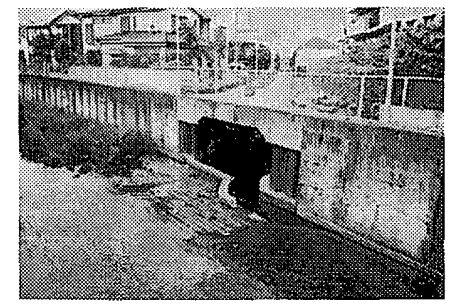

写真1 支流跡と白子川

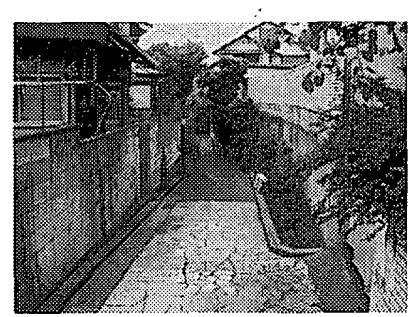

写真 2 練馬区大泉地区の用水路跡
なくても、雨水を川までゆっくりと流すことができると思わ れる。さらに、水路跡は流域住民の生活道路としても使われ ているため、川沿いの管理用通路注2と一体に活用すれば、回 遊性のあるせせらぎ散歩道ができると考えた。

\section{2 視点と目的}

既報 ‘では、白子川流域の水路跡の位置と幅、延長、それ らに隣接するオープンスペースの位置と数を文献とフィー ルドワークによって把握した。その結果、水路跡のせせら ぎ散歩道の資質を確認する際に、治水、利水、親水、生態 育成、環境教育といった効果に着目することが重要である とした。しかし、隣接土地を含めた大雨に対する雨水流出 抑制能力や、水路に流れる雨水の流量は算定していない。

そこで、流域に降った雨水をその場に一旦溜めて、水路 跡にゆっくりと流すことで、川へ雨水を一気に流出するこ とを抑制しながら雨水と親しむことができる治水効果に着 目し、次を目的とした。

(1)流域の水路跡と管理用通路、及び雨水を溜めることができ る隣接土地の位置と数、面積を把握すること。

(2)水路跡と管理用通路に隣接する公私土地に雨水を溜めて、 川への流出を抑制することによる治水効果を試算すること。 (3)公的土地に溜めた雨水を流寸水路を、大雨時には調整水

Research Assistant, Dept. of Arch., Faculty of Engineering, Tokyo University of Science

* 東京理科大学工学部建築学科 補手

East Japan Railway Company, Master of Architecture

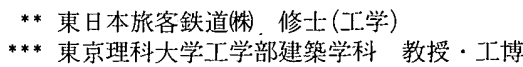


路、平常時にはせせらぎ水路にするための、水路断面の大き さを算定し、その水路に雨水が流れる日数を試算すること。

\section{3 位置付け}

野中ら ${ }^{2}$ は、流域を直接流出域加地下水流出域に区別し、 北川ら ${ }^{3}$ は田畑か森林、市街地といった土地利用で区別して 流出抑制施設による治水効果を試算している。賈ら ${ }^{4}$ は大 規模な単一の防災調節池による治水効果を試算している。 いずれも流域に点在する学校や公園といった土地用途別に 流出抑制施設を設けることは想定していない。また、大澤 $ら^{5}$ 、鶴田ら ${ }^{6}$ は、愛知県新川流域における宅地開発指導要 繝等による流出抑制施設の設置状況を把握し、小規模な開 発や既存敷地に対する制度の必要性を指摘している。

水空間の持つ親水効果を把握した研究には、村川ら ${ }^{7}$ の 都市親水施設が周辺環境に及ぼす影響を把握したものや、 畔柳 ${ }^{8}$ 、渡辺ら ${ }^{9}$ の都市部の水辺空間の利用者の行動特性 を把握したもの、紀谷ら ${ }^{10}$ 、小瀬ら ${ }^{11}$ の団地などの人工水景 施設が人間の行動へ及ぼす影響を把握したもの、上山ら ${ }^{12}$ の、都内親水公園の利用実態と住民の評価を把握したもの 等がある。しかし、いずれも河川や上水の空間を対象とし ており、雨水空間は扱っていない。

都市洪水に対しては行政の様々な取り組みが見られる。 1980 年に、河川だけでなく流域で雨水を貯留したり、浸透さ せて流出を抑制する総合治水という考えが示されたが、流域 の大部分を占める建築敷地には河川法が適用されない。ま た、流出抑制施設の設置に対する自治体の助成金制度がある が、施設の設置を義務付けるものではない。宅地開発要網で 流出抑制施設の設置を指導する自治体もあるが、大規模な開 発行為に対するもので、既存の政地や小規模な開発行為には 適用されない。このように、現在の法律や要網では、建筑敷 地での雨水流出抑制施設による治水効果を河川改修計画に反 映できない。1995 年には河川法で「河川立体区域制度」が設 けられ、放水路や調節池などの河川管理施設を、河川以外の 土地の下部等に設けることができるようになった。そして、 白子川流域には、既設の比丘尼橋上流調節池 $\left(3.4\right.$ 万 $\left.\mathrm{m}^{3}\right)$ に加 えて、この制度によって $75 \mathrm{~mm} / \mathrm{h}$ の雨量に対処するための比丘 尼橋下流地下調節池 $\left(21.2\right.$ 万 $\left.\mathrm{m}^{3}\right)$ が設けられた。さらに、東 京都は白子川も含めた都内の 46 本の河川を、降雨強度清3 $50 \mathrm{~mm} / \mathrm{h}$ に対応させるために河川改修を進めている。本論で は、このような河川区域だけで洪水対策を行なう治水効果に 対して、雨が降った建築敷地で雨水の流出を抑制すること が、どのくらいの治水効果を期待できるのかを試算する。

2. 水路跡と管理用通路、隣接土地の位置、数、延長、面積 2. 1 雨水調整区域と婳養域の設定

川近傍の低地は標高が低く、雨水を浸透させるよりも溜め ることが適しているため、水路跡と管理用通路、及びそれら に隣接する公私土地を「雨水調整区域」、その他の区域を、雨 水を浸透させて地下水の涵養の推進を図る「涵養域」とした （図 1 ）。公的土地は、雨水を眝留するための広い外部空間を 持っている学校と公園、公用緑地、公共集合住宅、神社・寺
とした。私的土地は学校、公共集合住宅、神社- 寺以外の宅 地と生産緑地とした (表 1 )。

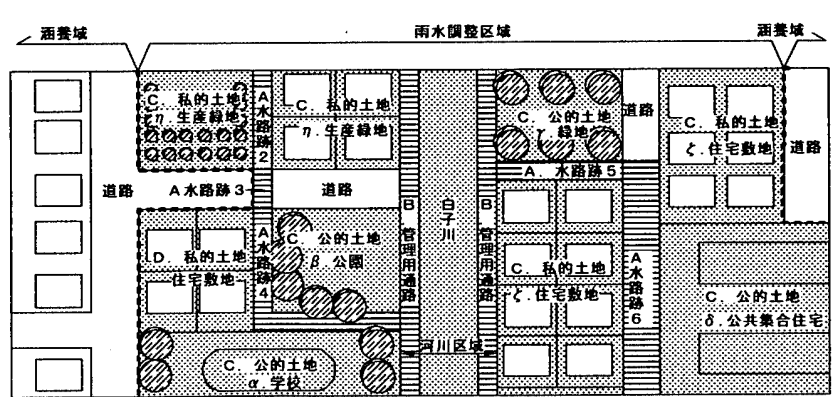

図 1 雨水調整区域と涵養域

\section{2 現状調査の項目と方法}

水路跡と管理用通路、公私土地の調查概要を表 1 に示す。な お、水路跡は既報 1 の調查結果に西東京市の水路跡を加えた。

\section{3 調查結果}

水路跡と管理用通路、隣接土地の位置と数、延長、面積を 算定した（表 2、3 と図 2)。その概要は次のとおりである。

水路跡は合計 387 本、総延長は約 $35 \mathrm{k} \mathrm{m}$ であった。この内、 水路の形態を残さず、面積や延長の算定が不可能なものを除 いた 362 本 (約 $34 \mathrm{~km}$ )を、以降で扱う試算の対象とした。こ の内、開渠は約 $1 \mathrm{~km}$ で、残りの約 $33 \mathrm{~km}$ は埋め立てられたり暗 渠となっていた。また、歩専道は約 $13 \mathrm{~km}$ 、車道は約 $20 \mathrm{~km}$ で、 歩道の約 9 割と車道の約 2 割は $4 \mathrm{~m}$ に満たない道であった。

管理用通路は合計 131 本で、白子川両岸の延長の約 7 割 (約 $14 \mathrm{~km}$ ) に通路があり、この約 6 割 (約 $8 \mathrm{~km}$ ) は歩専道であった。 また、通路の約 6 割 (約 $9 \mathrm{~km}$ ) は $4 \mathrm{~m}$ に満たない通路であった。

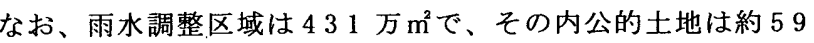
万 $\mathrm{m}^{2} 、$ 私的土地は約 243 万 $\mathrm{m}^{2}$ となった。

\section{表 1 調查概要}

\begin{tabular}{|c|c|c|c|c|c|}
\hline \multicolumn{5}{|c|}{ 調査項目 } & 方法 \\
\hline \multirow{3}{*}{\multicolumn{3}{|c|}{ A 水路䟽 }} & & 位涀一幅-延展 & 文缺 $13,14,15,16$ \\
\hline & & & 2 & 開渠・暗渠・埋め原し & フィールドワーク $(2003.8)$ \\
\hline & & & 3 & 多筑道・果道 & フィールドワーク $(2003.8)$ \\
\hline \multirow{2}{*}{\multicolumn{3}{|c|}{ B管理用通路 }} & & 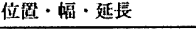 & 文献17 \\
\hline & & & 5 & 步尃道・車道 & フィールドワーク $(2003.8)$ \\
\hline \multirow{7}{*}{$\begin{array}{c}c \\
\text { 噇 } \\
\text { 接 } \\
\pm \\
\text { 地 }\end{array}$} & \multirow{5}{*}{ 公的 } & 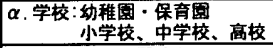 & 6 & 位澄・面程 & 文献17 \\
\hline & & \begin{tabular}{|c|}
$\beta$. 公園: 都市公園洼と \\
児童楅桂法上の公園 \\
\end{tabular} & 7 & 位圆 - 面程 & 文献17 \\
\hline & & $\begin{array}{c}r . \text { 公用緑地: 私有公用粶地と } \\
\text { 公有公用粶地 }\end{array}$ & 8 & 位圈・面皘 & 文献17,18 \\
\hline & & $\delta$. 公共集合住宅 & 9 & 位灌・面稍 & 文献17 \\
\hline & & $\varepsilon$. 神社・寺 & 10 & 位睲·面秙 & 文献17 \\
\hline & \multirow{2}{*}{$\begin{array}{l}\text { 私的 } \\
\text { 土地 }\end{array}$} & $\zeta$. 宅地 (住宅敖地とその他) & 11 & 位圈・面箖 & 文献17 \\
\hline & & n. 生産粶地 & & 位温・面稍 & 文献 $19,20,21,22$ \\
\hline
\end{tabular}

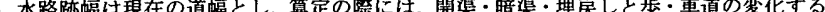
所、水路跡幅員上りも広い道が横切る所で水路跡を区分して数と延長を算定した。また、 暗渠とは河道幅冒を覆蓋化したもので、埋め戻しとは河道幅買を埋め立てたものとした。 B. 管理用通路は川边の既存の通路をすべて調查対象とし、橋間を1本として算定した。 C. 私有公用緑地とは、税制上の隻遇措固を受けて市民に開放されている民有の粶地とした。 また私的土地の宅地は、学校・神社・寺・公共集合住宅以外の宅地とし、店舗等の宅地も あるが、ここでは流域の大部分を占める住宅敷地とその他の敷地に区別した。

表 2 水路跡と管理用通路の数と延長

\begin{tabular}{|c|c|c|c|c|c|c|c|}
\hline \multicolumn{5}{|c|}{ A. 水路跡 } & \multicolumn{3}{|c|}{ B. 管理用通路 } \\
\hline \multirow{2}{*}{\multicolumn{2}{|c|}{ 聞䋗 }} & 数 (本) & 庭長 $(\mathrm{m})$ & 延長比事 (\%) & 数 (本) & 延長 (m) & 延長比事 (\%) \\
\hline & & 8 & 1,030 & 3 & & & \\
\hline \multirow{3}{*}{ 歩専道 } & $0<\mathbb{W}<4 m$ & 140 & 11,896 & 34 & 71 & 7,469 & 52 \\
\hline & $4 \leqq W$ & 16 & 1,454 & 4 & 5 & 460 & 3 \\
\hline & $0<\mathbb{W}<4 m$ & 48 & 3,862 & 11 & 13 & 1,556 & 11 \\
\hline 車道 & $4 \leqq W$ & 150 & 15,666 & 44 & 42 & 4,811 & 34 \\
\hline \multicolumn{2}{|c|}{ 形態不明 } & 25 & 1,336 & 4 & & & \\
\hline \multicolumn{2}{|l|}{ 合計 } & 387 & 35,243 & 100 & 131 & 14,296 & 100 \\
\hline
\end{tabular}




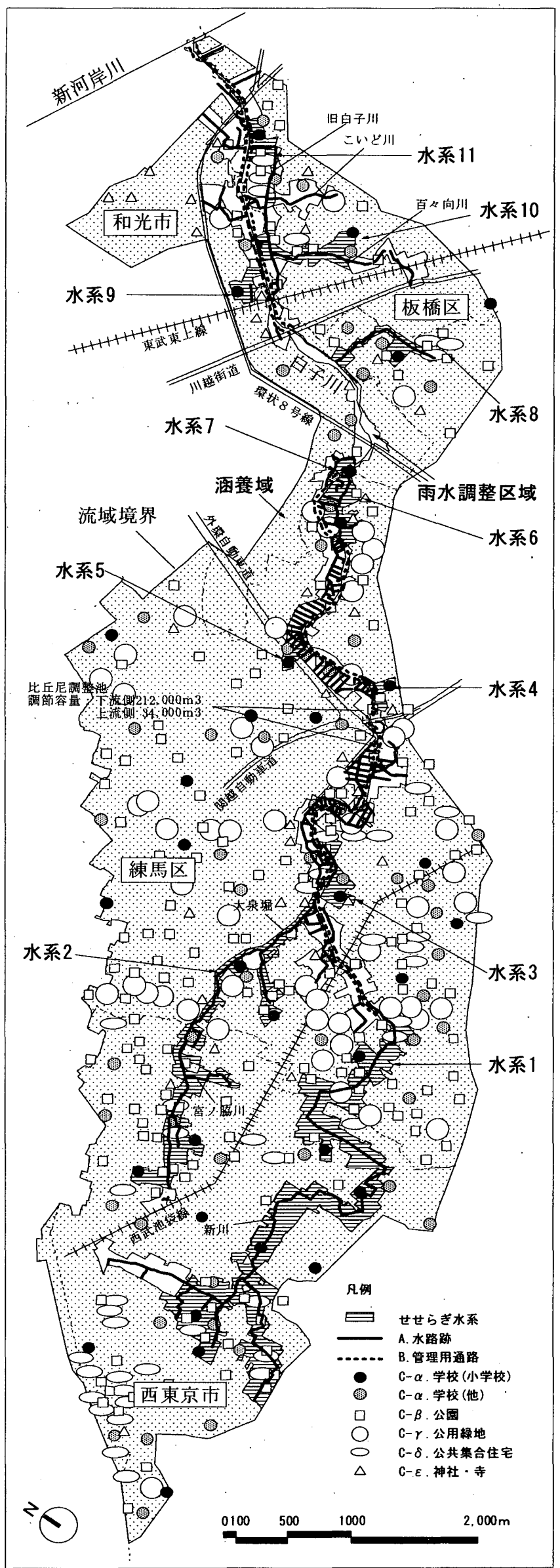

図 2 水路跡・管理用通路・公的土地の配置とせせらき水系
表 3 水路跡と管理用通路、隣接土地の数と面積

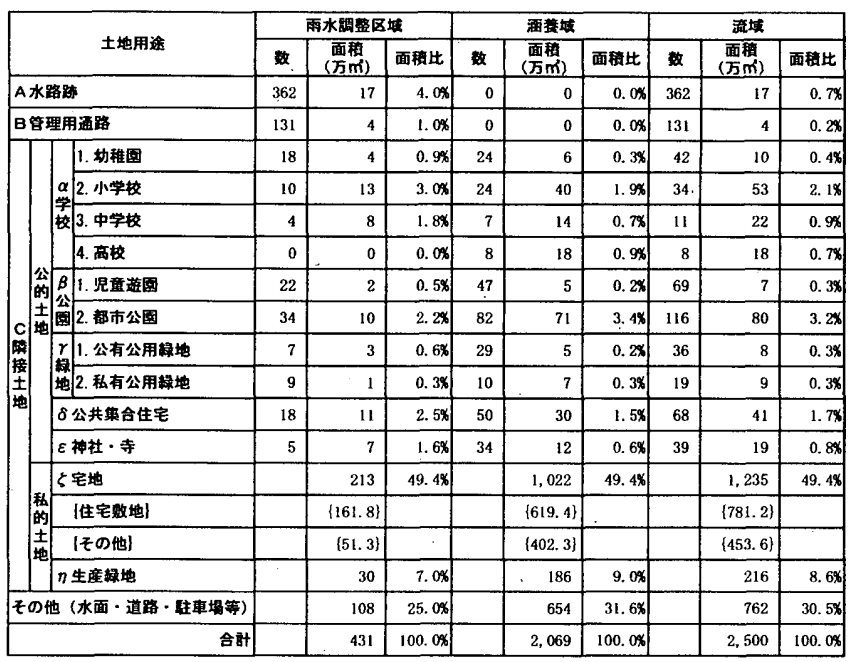

\section{3. 雨水流出抑制による治水効果の試算}

水路跡と管理用通路に隣接する土地で雨水を眝留すること が、どのくらいの治水効果をもたらすのかを、次のように試 算した（図３）。まず、雨水を貯留・浸透させた時の流出係数 を土地用途別に設定して、流域の平均流出係数を求め、その 時の川へ流れ込む雨量を求めた。次に、流出係数を河川の計 画に用いられる河川砂防技術基準23 で指定されている密集市 街地の平均流出係数の 0.9 とした場合の、大雨時に必要な洪 水調節容量を算定し、水路跡と管理用通路、それらに隣接寸 る公私土地に貯留可能な量と比較した。なお、大雨とは降雨 強度 $50 \mathrm{~mm} / \mathrm{h}$ とした。

\section{1 土地用途別流出係数の設定と流域の平均流出係数}

各土地に対する雨水流出係数を次のように設定した。緑地 と水路跡と管理用通路は、下水道計画で用いられる工種別基 礎流出係数 ${ }^{24}$ より各々 0.3 と 0.9 とした。学校、公園、神社・ 寺、住宅敷地の流出係数は、河川砂防技術基淮で示されてい る地域が開発される前の0.6 とした(表 4)。

そして、2 章で把握した流域の水路跡と管理用通路、公私 土地の面積と、設定した流出係数を式 1 に代入して流域全体 の平均流出係数を算定した結果、約 0.736 となった。式 2 よ り、流出係数 0.9 のときの流域から流出するピーク流量は $312.5 \mathrm{~m}^{3}$ 、流出係数 0.736 のときは $255.6 \mathrm{~m}^{3}$ である。白子川の 下流許容放流量は式 3 より $292.63 \mathrm{~m}^{3}$ であるため、平均流出係 数 0.736 として河川の計画を行えば、現在の白子川でも $50 \mathrm{~mm} /$ h に対応していることになる。すなわち、都市計画法や条例 で土地の用途に応じて流出倸数を定めることで、大規模な流 出抑制施設を新たに設けなくてもよいことがわかる。

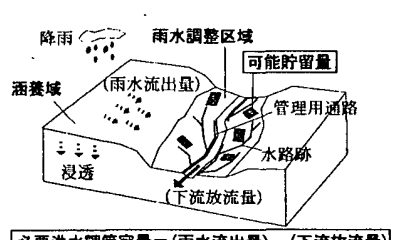

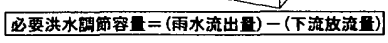
图 3 治水勃果の試算模式图
表 4 土地用途別の流出係数

\begin{tabular}{|c|c|c|c|c|c|}
\hline \multirow{2}{*}{\multicolumn{2}{|c|}{ 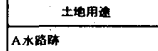 }} & 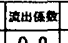 & \multicolumn{2}{|c|}{ 土地用海 } & \multirow{2}{*}{\begin{tabular}{|c|} 
zatu保圆 \\
0.3 \\
\end{tabular}} \\
\hline & & 0.9 & \multirow{2}{*}{\multicolumn{2}{|c|}{ 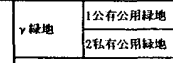 }} & \\
\hline \multicolumn{2}{|c|}{ 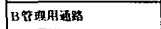 } & 0.9 & & & 0.3 \\
\hline \multirow{6}{*}{ 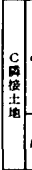 } & 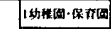 & 0.6 & \multicolumn{2}{|c|}{ C $\delta$ 公其然合任宅 } & 0.6 \\
\hline & 2小等交 & 0.6 & \multicolumn{2}{|c|}{ 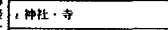 } & 0.6 \\
\hline & 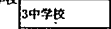 & 0.6 & 青菓 & 隹定烧地 & 0.6 \\
\hline & 4 4两校 & 0.6 & ; 宅曲 & 飞の地 & 0.9 \\
\hline & 先的者问 & 0.6 & \multicolumn{2}{|c|}{ 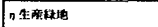 } & 0.3 \\
\hline & 2 28市公国 & 0.6 & \multicolumn{2}{|l|}{ もの地 } & 0.9 \\
\hline
\end{tabular}


平均流出係数の算定式

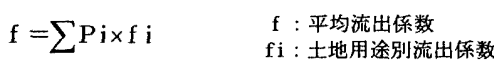

$$
\begin{aligned}
& \mathrm{Pi} \text { : 土地用途別面積比率 } \\
& Q=\frac{1}{360} \times \mathrm{f} \times \mathrm{r} \times \mathrm{A} \quad \begin{array}{l}
\mathrm{Q}: \text { ピーク容量 }(\mathrm{m} 3 / \mathrm{s}) \\
\mathrm{f}: \text { 流出保数 }
\end{array} \\
& \text { A: 集水面䅡 }\left(\text { 万 } \mathrm{m}^{2}\right) \\
& \mathrm{r}: t c \text { 内の平均降雨強度 }(\mathrm{m} m / \mathrm{h}) \\
& \text { tc: 洪水到達時間(分) }
\end{aligned}
$$

下流許容放流量 $(Q \mathrm{C})$ の算定式

$$
\begin{aligned}
& \mathrm{Qc}=\mathrm{A}_{\mathrm{i}} \times \mathrm{v} \quad \text { マニングの式 } \quad \mathrm{v}=\frac{1}{\mathrm{n}} \cdot \mathrm{R}^{\frac{2}{3}} \cdot 1^{\frac{1}{2}} \\
& A_{i}: \text { 流水断面 }\left(\mathrm{m}^{2}\right) \quad \mathrm{v}: \text { 流速 }(\mathrm{m} / \mathrm{s}) \\
& \mathrm{n} \text { : 粗度保数 (ここでは三面張り護岸の } \mathrm{n}=0.025 \text { を用いた } \\
& \mathrm{n}: \text { : 径深 }(\mathrm{m}) \mathrm{R}=\mathrm{A} \mathrm{i} / \mathrm{P} \quad \mathrm{P} \text { : 水路勾配 (白子川は } 1 / 250) \\
& \mathrm{P}: \text { 润辺 }(\mathrm{m}) \mathrm{P}=\mathrm{b}+2 \mathrm{H} \text { (白子川 } \mathrm{D}_{\mathrm{b}} \text { (水路幅) } 10.2 \mathrm{~m} 、 \mathrm{H} \text { (水路高さ) } 5.82 \mathrm{~m} \text { を用いた) }
\end{aligned}
$$

\section{2 大雨 $(50 \mathrm{~mm} / \mathrm{h})$ に対する必要洪水調節容量}

雨が降ったその場で、雨水の流出を抑制できなくても、近 くの公的土地に溜めることで治水効果を期待できる。そこ で、大雨時に洪水を調節するために必要な容量を算定した。 算定には、大規模宅地開発時の調節池技術基隻 25 の式 $3 \sim 6$ を 用いた。その結果、平均流出係数を 0.9 とした場合の必要洪 水調節容量は約 61 万 $\mathrm{m}^{3}$ となった。

\section{必要洪水調節容量の算定式}

$\mathrm{V}=\left(\mathrm{ri}-\frac{\mathrm{rc}}{2}\right) \cdot 60 \cdot \mathrm{ti} \cdot \mathrm{f} \cdot \mathrm{A} \cdot \frac{1}{360}$

$\mathrm{V}:$ 必要調節容量 $\left(\mathrm{m}^{3}\right) \quad \mathrm{t} \mathrm{i}:$ 降雨継続時間 $($ 分 $)$

$\mathrm{f}:$ 流出俰数 $\mathrm{A}:$ 集水面糟 $\left(\right.$ 万 $\left.\mathrm{m}^{2}\right)$

r i : 降雨強度 $(\mathrm{mm} / \mathrm{h})$ r c : 調整池下流の流過能力の値に対する降雨強度 $(\mathrm{mm} / \mathrm{h})$

\section{東京都の $50 \mathrm{~mm} / \mathrm{h}$ の降雨強度式}

$r i=\frac{1610}{\left(t i^{\frac{3}{4}}+10.27\right)} \quad t i:$ 降雨継続時間（分）

\begin{tabular}{|c|c|c|c|c|c|c|c|}
\hline & 土地用途 & 眝留場所 & 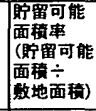 & 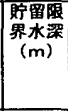 & 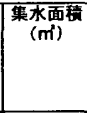 & 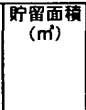 & $\mid \begin{array}{c}\text { 可能汿留曋 } \\
\left(\mathrm{m}^{3}\right)\end{array}$ \\
\hline & 1. 幼稚㯖・保产園 & & $39 \%$ & 0.2 & 39,962 & 15,585 & 3,117 \\
\hline & \begin{tabular}{|l|l|}
$\alpha$ & 2. 小学挍 \\
学
\end{tabular} & & $39 \%$ & 0.3 & 131,039 & 51,105 & 15,332 \\
\hline & 较 3. 中学挍 & & $42 \%$ & 0.3 & 78,930 & 33,151 & 9,945 \\
\hline 忩 & 4. 高校 & & $31 \%$ & 0.3 & 0 & 0 & 0 \\
\hline \pm & \begin{tabular}{|l|l|}
$\beta$ & 1 . 児重遊園
\end{tabular} & 筑山等を除く広最 & $60 \%$ & 0.2 & 20,728 & 12,437 & 2,487 \\
\hline & 園 2. 都市公圆 & 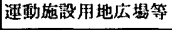 & $40 \%$ & 0.3 & 98,607 & 39,443 & 11,833 \\
\hline & $\delta$ 公共集合住宅 & 堜间粶地 & $37 \%$ & 0.3 & 108,990 & 40,326 & 12,098 \\
\hline & $\varepsilon$ 神社-寺 & & $40 \%$ & 0.3 & 27,637 & 11,055 & 3,316 \\
\hline
\end{tabular}

調整池下流の流過能力の值に対する降雨強度 $(r \mathrm{c})$

\begin{tabular}{|c|c|c|c|c|}
\hline & & & & 08,120 \\
\hline $\begin{array}{l}c \text { C } \\
\text { 和的 } \\
\text { 土地 }\end{array}$ & $\zeta$ 住宅票地 & 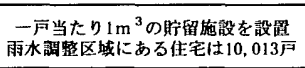 & & 10,013 \\
\hline
\end{tabular}

$\mathrm{rc}=\frac{360 \cdot \mathrm{Qc}}{\mathrm{f} \cdot \mathrm{A}} \quad Q \mathrm{c}:$ 下流許容放流量 $\left(\mathrm{m}^{3} / \mathrm{s}\right)$

\section{3 雨水調整区域の可能賍留量}

雨水調整区域の公私土地に雨水を貯留できる容量を次のよ うに算定した。まず、公私的土地に設ける貯留施設の敷地に 対する面積率と眝留限界水媣を流域貯留施設設計指針 ${ }^{26}$ の基 潐を用いて設定した（表 5 )。なお、緑地は雨水の保水能力が

表 5 公私土地の敷地に対する質留可能面積率と貯留限界水 深と可能貯留量

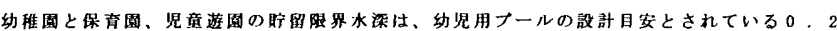
$\mathrm{m}$ とし、小中学校の眝的限界水梅は廷、公園は $0.3 \mathrm{~m}$ とした。
あるため、眝留施設を設ける想定はしなかった。また、住宅 敷地についての指針はないため、雨水利用を目的とした $1 \mathrm{~m}$ 3 の貯留槽等を設置することを想定した。そして、雨水調整 区域の公私土地の可能貯留量を算定した (表 5)。その結果、雨 水調整区域の公的土地では約 5.8 万 $\mathrm{m}^{3}$ 、私的土地では約 1 万 $\mathrm{m}^{3}$ の雨水を貯留可能であることがわかった。

\section{4 洪水必要調節容量と可能貯留量の比較}

公私土地の可能貯留量を合計した約 6.8 万 $\mathrm{m}^{3}$ は、白子川 比丘尼橋上流調節池 $\left(3.4\right.$ 万 $\left.\mathrm{m}^{3}\right)$ の約 2 倍に相当する。ま た、流出係数を 0.9 としたときの必要洪水調節容量約 61 万 $\mathrm{m}^{3}$ から、公私土地の可能貯留量 6.8 万 $\mathrm{m}^{3}$ を引いた 54.2 万 $\mathrm{m}^{3}$ が、白子川に求められる容量である。白子川の延長を $10 \mathrm{~km}$ 、幅 $10.2 \mathrm{~m}$ とすると、その梁さは $5.3 \mathrm{~m}$ でよいことに なる。現在の白子川の深さは平均 $5.82 \mathrm{~m}$ であるから、流域 の平均流出係数を 0.9 としても、雨水調整区域に雨水貯留 施設を設ければ、 $50 \mathrm{~m} \mathrm{~m} / \mathrm{h}$ に対応することが可能になる。

\section{4: 調整水路とせせらぎ水路の断面検討}

水路跡に設ける水路を、大雨時には「調整水路」、平常降 雨後には「せせらぎ水路」にするために、必要な水路断面を 次のように検討した。

まず、水路跡と隣接する公的土地のまとまりをせせらぎ水 系として設定した。ここでは、水路跡に流す水質の保障がで きる公有の学校、公園、公共集合住宅に溜めた雨水を水源に することを想定した。次に、大雨時に公的土地に降った雨水 がその貯留施設へ流れ込む雨水の最大流入量（a）を求めた。 また、公的土地から水路跡へ雨水を流寸放流孔の大きさを算 定して、その放流孔から水路跡一流孔出る最大放流量 (b) を 算定した。この最大放流量 (b) と水路跡に降る最大雨量 (c) の 和を、大雨時に水路跡に流れる最大雨量 $(\mathrm{d})$ とした (図 4 )。そ して、この雨水を流すことができる調整水路の断面と、平常 降雨後に雨水を流すせせらぎ水路断面の大きさを算定した。

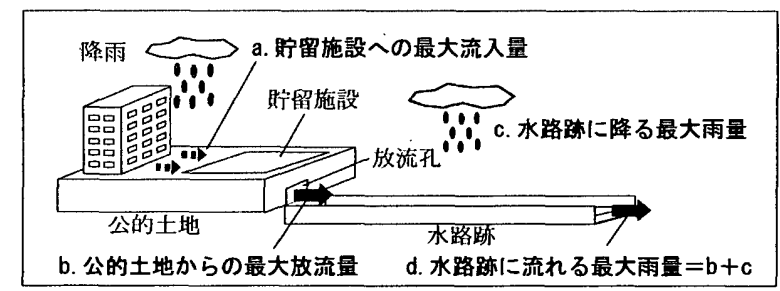

図 4 水路跡に流れる最大雨量の算定模式図

\section{1 せせらぎ水系の設定}

通学区域に雨水調整区域を含む 27 の小学校を対象に、各小 学校が指定している通学路を聞き取り(2003 年 12 月)によっ て把握した。聞き取りの対象は、西東京市と練馬区、和光市 は各自治体の教育委員会、板橋区は各小学校とした。その結 果、水路跡を指定通学路としている小学校は 19 校あった。そ れらの小学校を基点とした 11 のまとまりを「せせらぎ水系」 とした（図 2 ）。なお、基点とした小学校以外の公的土地には、 雨水調整区域内の近接している土地も含めた。そして、各水 系の延長、面積、勾配と公的土地の数を算定した（表6）。 
表 6 せせらぎ水系の構成

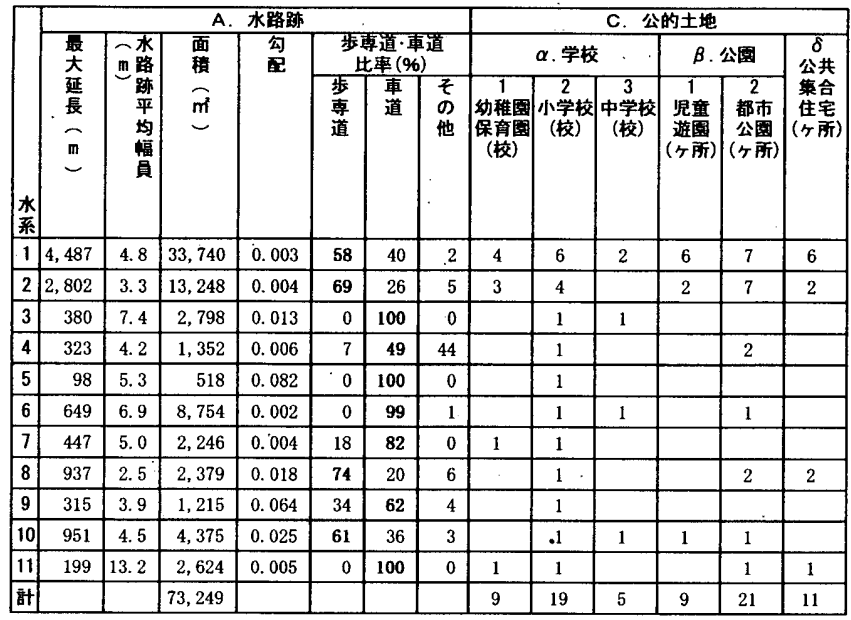

\section{2 公的土地の貯留施設への最大流入量 (a )}

各公的土地の平均面積を算定し、降雨継続時間と降雨強度 の関係を示す計画降雨波形を式 4 より作成した。その際、中 央集中型降雨波形を用いた。降雨継続時間は 24 時間とし、洪 水到達時間は、河川の設計に用いる流域の面積に比べ公的土 地の面積が極めて小さいため 10 分とした。そして、降雨時間 毎に各公的土地に降る雨量を式 2 によって求め、流入八イド ログラフを作成し（図 5 ) 、公的土地用途別にその貯留施設人 流れ込む雨水の最大流入量 (a ) を算定した (表 7)。

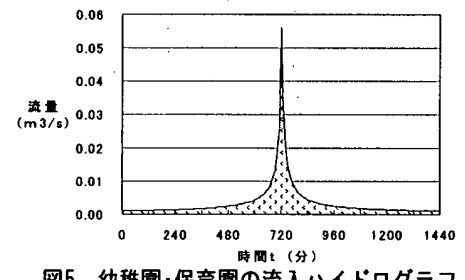

図5 幼稚園·保育園の㐬入ハイドログラフ

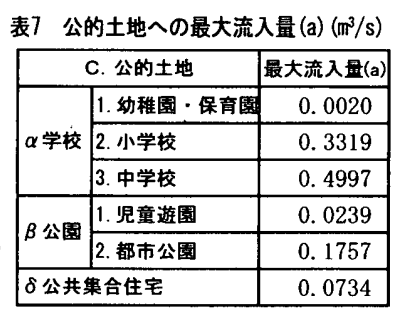

\section{3 公的土地に設ける放流孔の大きさ}

各公的土地の流入ハイドログラフより、その土地の貯留施 設に溜まる雨量を降雨時間毎に式 7 を用いて算定し、その最 大貯留量が各貯留施設の可能貯留量を超えない最小の放流孔 の大きさを算定した（表 8 ）。なお、各公的土地の貯留施設の 四方に幅 $0.3 \mathrm{~m} \times$ 深さ $0.3 \mathrm{~m}$ の側溝を設け、その 1 ヶ所に放流 孔を設置するものとした。

表 8 公的土地に設ける放流孔の大きさ

\begin{tabular}{|c|c|c|c|c|c|c|c|}
\hline & \multicolumn{6}{|c|}{ c. 公的土地 } \\
\hline & & \multicolumn{3}{|c|}{$\alpha$. 学校 } & \multicolumn{2}{|c|}{ B. 公葍 } & \multirow{2}{*}{$\begin{array}{c}\delta . ~ \text { 公共 } \\
\text { 集合 } \\
\text { 住宅 }\end{array}$} \\
\hline & & 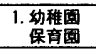 & 2. 小学校 & 3. 中学校 & 1. 児童遊園 & 2. 都市公園 & \\
\hline \multirow{3}{*}{ 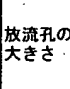 } & 曋B $(\mathrm{m})$ & 0.01 & 0.06 & 0.05 & 0.01 & 0.02 & 0.04 \\
\hline & 高さD $(m)$ & 0.03 & 0.04 & 0.04 & 0.01 & 0.02 & 0.04 \\
\hline & 断面积（副） & 0.0012 & 0.0022 & 0.0020 & 0.0001 & 0.0004 & 0.0014 \\
\hline
\end{tabular}

\section{4 放流孔からの最大放流量 (b)}

\section{（1）大雨時の公的土地 1 ヶ所からの最大放流量}

降雨時間別に放流孔から流出する雨量を式 2 によって求め、 流出ハイドログラフを作成して各公的土地の 1 ケ所からの最 大放流量を算定した（図 6 と表 9 ）。

\section{（2）平常降雨後の公的土地 1 ヶ所からの最大放流量}

理科年表 ${ }^{27}$ によると東京の年間平均降水量は $1466.7 \mathrm{~m} \mathrm{~m}$ で、 平均降雨日数 100.6 日であるから、平常降雨はこの年間降水 量を降雨日数で除した $14.7 \mathrm{~mm} /$ 日と仮定し、その降雨量を公 的土地に溜めた時の貯留施設の水深を求め、式 7 より公的土 地の放流孔から流れる最大放流量を算定した（表 9 )。

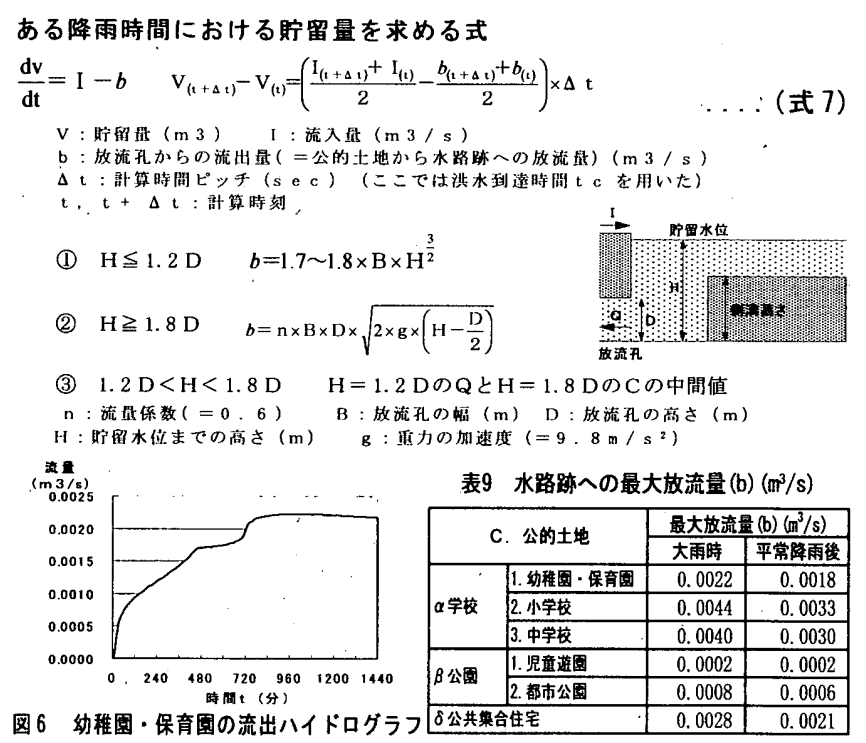

4.5 水路跡に流れる最大雨量 (d)

（1）大雨時に水路跡に流れる最大雨量 $\left(\mathrm{d}_{\text {大 }}\right)$

大雨時に各水系の水路跡に流れる最大雨量 $\left(\mathrm{d}_{\text {大 }}\right)$ は、4.4 (1) で求めた公的土地 1 ケ所からの最大放流量に、各水系を構成 する公的土地の数を乗じたものと、各水系の水路跡に降る最 大降雨 (c) を合計したものとして算定した（表 10 )。なお、大 雨時の水路跡に降る最大雨量 (c) は、各水系を構成する水路 跡の総面積に応じた流入ハイドログラフを作成して求めた。

表 10 水路跡に流れるの最大雨量 (d)

\begin{tabular}{|c|c|c|c|c|}
\hline \multirow[b]{2}{*}{ 水系 } & \multicolumn{3}{|c|}{ 大雨時 } & \multirow{2}{*}{\begin{tabular}{|l|} 
平常降雨後 \\
水路跡に二流れる \\
最大雨量 $\left(\mathrm{d}_{\text {平 }}\right)$ \\
$\left(\mathrm{m}^{3} / \mathrm{s}\right)$ \\
\end{tabular}} \\
\hline & $\begin{array}{l}\text { 公的土地からの } \\
\text { 最大放流贵 (b) } \\
\left(\mathrm{m}^{3} / \mathrm{s}\right)\end{array}$ & \begin{tabular}{|c} 
水路跡に降る \\
最大雨量 $(\mathrm{c})$ \\
$\left(\mathrm{m}^{3} / \mathrm{s}\right)$
\end{tabular} & $\begin{array}{c}\text { 我路跤に流れる } \\
\text { 最大雨昜 }\left(\mathrm{d}_{\star}\right)=\mathrm{b}+\mathrm{c} \\
\left(\mathrm{m}^{3} / \mathrm{s}\right)\end{array}$ & \\
\hline 1. & 0.101 & 0.854 & 0.955 & 0.051 \\
\hline 2 & 0.057 & 0.336 & 0.393 & 0.027 \\
\hline 3 & 0.014 & 0.071 & 0.084 & 0.006 \\
\hline 4 & 0.011 & 0.034 & 0.045 & 0.005 \\
\hline 5 & 0.009 & 0.013 & 0.023 & 0.003 \\
\hline 6 & 0.014 & 0.222 & 0.236 & 0.007 \\
\hline$\overline{7}$ & 0.012 & 0.057 & 0.069 & 0,005 \\
\hline 8 & 0.017 & 0.060 & 0.077 & 0.009 \\
\hline 9 & 0.009 & 0.031 & 0.040 & 0.003 \\
\hline 10 & 0.015 & 0.111 & 0.126 & 0.007 \\
\hline 11 & 0.015 & 0.066 & 0.082 & 0.008 \\
\hline
\end{tabular}

\section{(2) 平常降雨後に水路跡へ流れる最大雨量 $\left(\mathrm{d}_{\text {平 }}\right)$}

平常降雨後に各水系の水路跡に流れる最大雨量 $\left(\mathrm{d}_{\text {平 }}\right)$ は、 4. 4 で求めた公的土地 1 ケ所から水路跡への最大放流量に、 各水系を構成する公的土地数を乗じたものとした（表１０）。

\section{6 調整水路とせせらぎ水路の幅と流速}

4. 5 で算定した雨量を、大雨時及び平常降雨後に水路跡に 流すための、水路の幅と流速を式 3 を用いて次のように算定 した。なお、水路勾配は各水系の勾配（表 6 ）を用いた。 
大雨時の水路幅と流速は、児童・生徒の安全確保のために 最大水深を $0.3 \mathrm{~m}$ として、水路幅と流速、水深を算定した（表 11 )。平常降雨後の水路幅と流速、水深は、次のように算定 した。まず、大雨時の水路幅が $0.3 \mathrm{~m}$ 以下の場合は、平常時 の水路幅も同じとした (水系 $4 、 8 、 9)$ 。大雨時の水路幅が 0.3 $\mathrm{m}$ を超えるものは水路幅を $0.3 \mathrm{~m}$ として、水深と流速を算定し

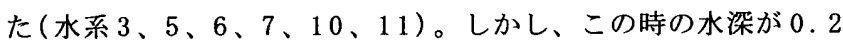
$\mathrm{m}$ （幼児用プールの安全設計上の指標）を超えるものは、水 深を $0.2 \mathrm{~m}$ として水路幅を広くした(水系 $1 、 2) 。$

なお、親水行為に適した流速は、文献 ${ }^{28}$ によると $0.2 \sim 0.6$ $(\mathrm{m} / \mathrm{s})$ とされており、この流速に適合する水系は $1 、 2 、 3 、$ $4 、 6 、 7 、 8 、 10 、 11$ の 水系、総延長は約 $16 \mathrm{~km}$ であった。

表 11 大雨時の水路断面と流速

\begin{tabular}{|c|c|c|c|c|c|c|c|c|}
\hline \multirow[b]{2}{*}{ 水系 } & \multicolumn{4}{|c|}{ 大雨時 } & \multicolumn{4}{|c|}{ 平常降雨後 } \\
\hline & $\begin{array}{c}\text { 就盘 }\left(d_{\star}\right) \\
\left(\mathrm{m}^{3} / \mathrm{s}\right)\end{array}$ & $\begin{array}{l}\text { 水梁 } \\
\text { (m) }\end{array}$ & 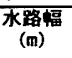 & $\begin{array}{l}\text { 硫速 } \\
(\mathrm{m} / \mathrm{s})\end{array}$ & $\begin{array}{c}\text { 流盘 }\left(\delta_{\text {平 }}\right) \\
\left(\mathrm{m}^{3} / \mathrm{s}\right)\end{array}$ & $\begin{array}{l}\text { 永深 } \\
\text { (畂) }\end{array}$ & $\begin{array}{c}\text { 水路楅 } \\
(\mathrm{m})\end{array}$ & 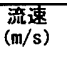 \\
\hline 1 & 0.955 & 0.30 & 4.50 & 0.711 & 0.051 & 0.20 & 0.61 & 0.399 \\
\hline 2 & 0.393 & 0.30 & 1.75 & 0.769 & 0.027 & 0.20 & 0.33 & 0.417 \\
\hline 3 & 0.084 & 0.30 & 0.33 & 0.858 & 0.006 & 0.05 & 0.30 & 0.428 \\
\hline 4 & 0.045 & 0.30 & 0.28 & 0.548 & 0.005 & 0.06 & 0.28 & 0.317 \\
\hline 5 & 0.023 & 0.30 & 0.35 & 2.196 & 0.003 & 0.02 & 0.30 & 0.646 \\
\hline 6 & 0.236 & 0.30 & 1.70 & 0.479 & 0.007 & 0.12 & 0.30 & 0.215 \\
\hline 7 & 0.069 & 0.30 & 0.42 & 0.553 & 0.005 & 0.07 & 0.30 & 0.293 \\
\hline 8 & 0.077 & 0.30 & 0.28 & 0.938 & 0.009 & 0.06 & 0.28 & 0.542 \\
\hline 9 & 0.040 & 0.30 & 0.12 & 1.141 & 0.003 & 0.04 & 0.12 & 0.699 \\
\hline 10 & 0.126 & 0.30 & 0.35 & 1.141 & 0.007 & 0.05 & 0.30 & 0.593 \\
\hline 11 & 0.082 & 0.30 & 0.46 & 0.607 & 0.008 & 0.08 & 0.30 & 0.330 \\
\hline
\end{tabular}

\section{7 せせらぎ散歩道タイプの検討}

4.6 で算定した調整水路とせせらぎ水路の幅を水路跡幅か ら引いた残りの道幅を求め、それが歩専道か車道として機能 するか否かを検討した（図７）。

タイプア：水系 1 は、平常時に必要な水路幅は $0.6 \mathrm{~m}$ である ため、道幅 $4.2 \mathrm{~m}$ を確保できる。しかし、多くの公的土地が 隣接しているため、その水路に流れる雨量も多く、大雨時に 必要な水路幅は $4.5 \mathrm{~m}$ となり、道幅全体を調整水路とする必 要がある。なお、この水系を構成する水路跡は暗渠となって いるため、その溝渠を利用することも可能である。

タイプイ:水系 2 と 10 は歩専道の部分が多い。水系 2 の道幅 はもともと狭いが、大雨時でも歩行者の通行幅 $1.5 \mathrm{~m}$ 以上は 確保でき、水系 10 は、常に道幅 $4 \mathrm{~m}$ 以上確保できる。よって、 いずれも大雨時に水路幅が拡がるが、常に歩行者が通れるせ せらぎ散歩道とすることが可能と思われる。

タイプウ: 水系 $3 、 5 、 6 、 7 、 11$ は車道の部分が多く、大雨時 に水路幅が拡がるが、道幅 $4 \mathrm{~m}$ 以上確保できるため、車の通行 幅を確保したせせらぎ散歩道とすることが可能と思われる。

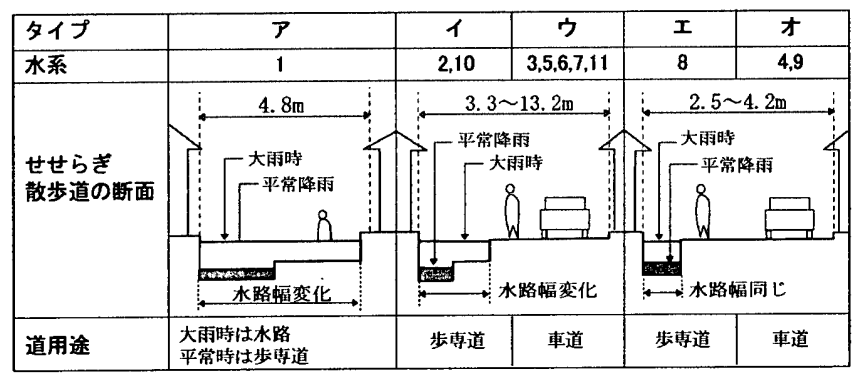

図 7 せせらぎ散歩道タイプ
タイプエ : 水系 8 の平均幅員は $2.5 \mathrm{~m}$ と狭いが、大雨時と平常 時共に必要な水路幅は $0.3 \mathrm{~m}$ であるため、歩行者の通行幅を確 保したせせらぎ散歩道とすることが可能と思われる。

タイプオ：水系 $4 、 9$ はは車道の部分が多いが、大雨時と平常 時共に必要な水路幅は $0.3 \mathrm{~m}$ である。よって、常に車の通行幅 を確保したせせらぎ散歩道とすることがが可能と思われる。

したがって、水路跡に設ける水路は、大雨時に雨水を川ま でゆっくりと流す調整水路としての資質が高いといえる。

\section{5. せせらぎ水路に雨水が流れる日数}

水路跡に雨水を日常的に流すことができれば、高い親水効 果を望むことが可能と思われる。そこで、4 章で検討したせ せらぎ水路に、どのくらいの期間雨水を流すことができるか を算定した。

\section{1 公的土地から雨水が流れ出る日数}

降水量 $1,10,30,50 \mathrm{~mm}$ 以上/日別に、公的土地に降った雨水 が平常降雨後に水路跡に流れ出る湛水日数を式 8 を用いて算 定した（表 12 ）。その湛水日数と降雨日数の和をせせらぎ水 路に雨水が流れ出る日数とした。なお、降雨後に雨水が流れ る日と降雨日の重複は考慮しないことにし、降雨日数は理科 年表 ${ }^{27}$ の記録を用いた。算定の結果、降雨日数 101 日に対し、 中学校から流れる日数が一番長く、年間約 213 日間雨水が流 れることがわかった。

\section{湛水時間の算定式}
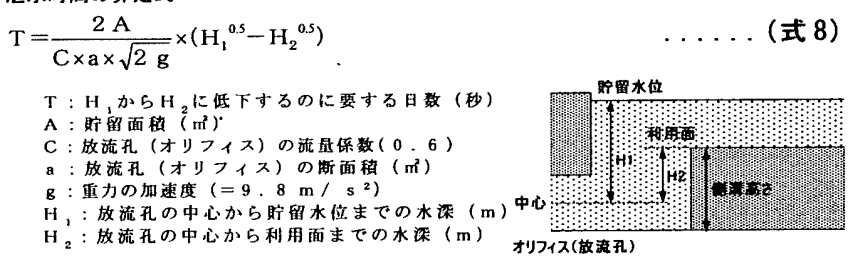

表 12 公的土地別にみた雨水が水路跡に流れ出る日数

\begin{tabular}{|c|c|c|c|c|c|c|}
\hline \multicolumn{2}{|c|}{$\begin{array}{c}C \\
\text { 公的土地 }\end{array}$} & \multirow[t]{2}{*}{$\begin{array}{c}\text { 降雨量 } \\
\text { (mm) }\end{array}$} & $\begin{array}{c}\text { 降雨日数 } \\
\text { (日) }\end{array}$ & $\begin{array}{l}\text { 降雨後の } \\
\text { 湛水日数 } \\
\text { (日) }\end{array}$ & $\begin{array}{l}\text { 年間 } \\
\text { 湛水日数 } \\
\text { (日) }\end{array}$ & $\begin{array}{c}\text { 水路跡に雨水 } \\
\text { 流れる日数 } \\
\text { (日) }\end{array}$ \\
\hline \multirow{16}{*}{$\begin{array}{l}\alpha \\
\text { 学 } \\
\text { 交 }\end{array}$} & \multirow{6}{*}{$\begin{array}{l}1 \\
\text { 幼 } \\
\text { 稚 } \\
\text { 園 }\end{array}$} & & & (6) & & \\
\hline & & $1 \sim 9$ & 56.3 & 0.07 & 4.2 & 60.5 \\
\hline & & $10 \sim 29$ & 31.6 & 0.28 & 8.9 & 40.5 \\
\hline & & $30 \sim 49$ & 8 & 0.55 & 4.4 & 12.4 \\
\hline & & $50 \sim$ & 4.7 & 0.69 & 3.2 & 7.9 \\
\hline & & & 100.6 & & 20.8 & 121.4 \\
\hline & & $1 \sim 9$ & 56.3 & 0.24 & 13.7 & 70.0 \\
\hline & 2 & $10 \sim 29$ & 31.6 & 0.92 & 29.0 & 60.6 \\
\hline & 小 & $30 \sim 49$ & 8 & 1.79 & 14.3 & 22.3 \\
\hline & & $50 \sim$ & 4.7 & 2.22 & 10.4 & 15.1 \\
\hline & & 計 & 100.6 & & 67.4 & 168.0 \\
\hline & & $1 \sim 9$ & 56.3 & 0.40 & 22.6 & 78.9 \\
\hline & 3 & $10 \sim 29$ & 31.6 & 1.52 & 48.1 & 79.7 \\
\hline & 中 & $30 \sim 49$ & & 2.98 & 23.8 & 31.8 \\
\hline & 校 & $50 \sim$ & 4.7 & 3.70 & 17.4 & 22.1 \\
\hline & & 計 & 100.6 & & 112.0 & 212.6 \\
\hline \multirow{10}{*}{ 葍 } & & $1 \sim 9$ & 56.3 & 0.38 & 21.1 & 77.4 \\
\hline & 児 & $\frac{1029}{10 \sim 29}$ & 31.6 & 1.44 & 45.4 & 77.0 \\
\hline & 童 & $30 \sim 49$ & & 2.84 & 22.7 & 30.7 \\
\hline & 遊 & $50 \sim$ & 4.7 & 3.54 & 16.7 & 21.4 \\
\hline & 園 & 竐 & 100.6 & & 105.8 & 206.4 \\
\hline & 2 & $1 \sim 9$ & 56.3 & 0.29 & 16.3 & 72.6 \\
\hline & 都 & $10 \sim 29$ & 31.6 & 1.10 & 34.7 & 66.3 \\
\hline & 市 & $30 \sim 49$ & 8 & 2.15 & 17.2 & 25.2 \\
\hline & 公 & $50 \sim$ & 4.7 & 2.67 & 12.6 & 17.3 \\
\hline & 園 & 計 & 100.6 & & 80.8 & 181.4 \\
\hline \multirow{5}{*}{\multicolumn{2}{|c|}{$\begin{array}{r}\delta \text { 公共 } \\
\text { 集合 } \\
\text { 住宅 }\end{array}$}} & $\frac{1 \sim 9}{1 \sim 9}$ & 56.3 & 0.20 & 11.3 & 67.6 \\
\hline & & $10 \sim 29$ & 31.6 & 0.76 & 23.9 & 55.5 \\
\hline & & $30 \sim 49$ & 8 & 1.47 & 11.7 & 19.7 \\
\hline & & $50 \sim$ & 4.7 & 1.69 & 8.0 & 12.7 \\
\hline & & & 100.6 & & 54.9 & 55.5 \\
\hline
\end{tabular}




\section{2 世せらぎ水系に雨水が流れる日数}

公的土地から流れる最大の日数を、各水系に雨水が流れる 日数とすると、最も雨水が流れる日数が長い水系は、中学校 を含む水系 $1 、 3 、 6 、 10$ の 4 水系であり、年間降雨日数の約 2 倍である。全水系には小学校が隣接しているため、少なく ても 168 日間は雨水がせせらぎ水路に流れることが予測でき る。したがって、水路跡に設ける水路は、治水だけでなく日 常的に雨水に親しむことができるせせらぎ水路としての資質 が高いといえる。

\section{6: まとめ}

流域に降った雨水をその場で一旦溜めて、水路跡にゆっく りと流すことで、雨水の流出を抑制する治水効果を試算し た。その結果を次のようにまとめた。

(1)水路跡は、白子川流域に張り巡らされており、上流から中 流域に多く、その延長は約 $35 \mathrm{~km}$ で、そのほとんどが埋め立て られたり、蓋がかけられた暗渠となっていた。また、歩専道 の水路跡は約 $13 \mathrm{~km}$ 。全体の約 4 割は $4 \mathrm{~m}$ に満たない狭い道で あった。管理用通路は約 $14 \mathrm{~km}$ あり、その内約 $7 \mathrm{~km}$ は歩専道。 全体の約 6 割は $4 \mathrm{~m}$ に満たない狭い道であった。

(2)現在、河川断面の計画に用いられている市街地の平均流出 係数は 0.9 に対し、雨水を眝留や浸透させることを想定した 流域の平均流出係数を求めると約 0.736 となり、この流出係 数で河川の計画を行なえば、現在の白子川は既に $50 \mathrm{~mm} / \mathrm{h}$ に対 応していることがわかった。

(3)流域の流出係数を 0.9 としても、水路跡と管理用通路、及 び隣接する公私土地に雨水を貯留すれば、約 6.8 万 $\mathrm{m}^{3}$ の洪水 調整容量をもつことができ、これ以上川を掘り下げなくても 降雨強度 $50 \mathrm{~mm} / \mathrm{h}$ の大雨に対応することが可能になる。 (4)公的土地に降った降雨強度 $50 \mathrm{~m} \mathrm{~m} / \mathrm{h}$ までの雨水を、下水道に 流さずに、水路跡を使って川までゆっくりと流すことができ ることを、水路に流れる雨量の試算によって確認した。また、 水路跡に小学校が隣接していれば年間 168 日間、敷地面積が 広い中学校が隣接していれば年間 212 日間、雨水のせせらぎ を楽しむことが可能と思われる。

\section{7. 成果と課題}

水路跡と管理用通路、及び隣接土地を活用した雨水流出抑 制によって、治水効果を期待するだけでなく、雨水と親しむ ことができるせせらぎ散歩道ができることを、降雨強度に応 じた雨水の流量試算により確認したこと。その治水効果を河 川計画に反映するために、建築敷地に適用される法律によっ て、水路跡と管理用通路の隣接土地からの雨水流出量を抑制 する考えを提案したことが本研究の成果である。

過去の出水事例の観測值と計算值を比較することで、試算 結果の妥当性を検証すること。また、提案した流出係数の他 流域への汎用性の確認と、私有地から流れ出る雨水の受け止 め方を検討すること。さらに、水路跡のせせらぎ散歩道とし ての資質の高さを、利水、親水、生態育成、気侯調整といっ た効果によって重みづけることが今後の課題である。
謝辞 水路跡と管理用通路のフィールド調查において、当時 卒業研究生であった松崎泰輔君と横山聡君の協力を得た。こ こに感謝の意を表します。

\section{注}

1 水路跡:がての支流や用水路の跡で、国有であるが、区や市が管理している。

2 管理用通路：河川改修に伴って、堤防内に幅員 3m以上の管理用通路を整備するこ とが、河川法河川管理施設等構造令第 27 条 9 と河川管理施設等構造令施工規則第 15 条10で義務付けられており、水防活動のための緊急車両や河川の維持管理のため の車両が通行する幅員を持った通路のこと。

3 降雨强度 $30 \mathrm{~mm}$ 忙 1 年に 1 回の確率で起こり、同 $50 \mathrm{~mm}$ 、同 $75 \mathrm{~mm}$ は、それぞれ 3 年、10 年に 1 度の確率で起こる降雨量のこと。

\section{参考文献}

1 市川，鈴木: 白子川流域水路跡のせせらぎ散歩道としての資質検即のための基磷調 查、日本建築学会計画系論文集、第 569 号、pp. 1-6、2003.7

2 野中樹夫 : 防災調節池の洪水流出抑制効果の検乾、士木学会年次学術講演会請演概 要集第 2 部 $\mathrm{Vol}: 48$ 巻、pp. 202-203、1993

3 北川善広、川登, 野中樹夫 : 流出解析に基つく雨水眝留施設の流出抑制効果の検 吋、土木学会踚文集 II 巻 497/II-28 号、pp. 21- 29、1994. 8

4 賈仰文、婗广恒、木内豪、吉谷純一、河原能久、未次忠司 : 分布型モデルを用いた 都市河川流域における流出抑制施設の効果の比較、水工学論文集 Vol:45 巻、 pp. 109-114、2001

5 大澤依莉、鶴田佳子 : 水害危険区域における開発許可システムに関する研究ーその 1 新川流域市町における雨水流出抑制施設設固の実態一、日本建築学全学術講演 梗概集、N0.7201、2003.9

6 鹤田佳子、大澤依莉：水害危険区域における開発許可システムに関寸る研究一その 2 新川流域総合治水における雨水流出抑制に関寸る行政指導の実態一、日本建策 学会学術諈演梗概集、N0.7202、2003.9

7 村川三郎、西名大作、飯尾昭彦: 都市内親水施設を対象とした距離圈域による住民 の利用・評価の分析、日本建築学会計画系論文報告集第 389 号、pp. 53-61、 1988. 7

8 畔柳昭雄、海辺秀俊: 都市臨海部の水辺空間における利用者の親水活動特性に関する 研究一都市住民の親水行動特性に関寸る研究 その 3 -、日本建筑学会計画系論文 集、第 459 号、pp. 195-203、1994.5

9 渡辺秀俊、畔柳昭雄、近藤垏雄 : 都市化に伴う住民の意践・行動変化から見た親水行 動特性に関する研究一都市住民の親水行動特性に関する研究 その1一、日本建築学 会計画系論文集、第 449 号、pp. 151-161、1993.7

10 紀谷文樹、小頼博之：水固施設における人の带留行動の解析，日本建勧学会計画系 論文集、第 507 号、pp. $35-40 、 1998.5$

11 小瀬博之、紀谷文樹 : 画像処理を用いた水景施設における人の行動と周辺摆境の解 析一水景施竞における人の行動と周辺噮境の解析に関する研究 その 2 -、日本建 築学会計画系踰文集、第 509 号、pp. 65-70、1998.7

12 上山肇、若山治临、北原理雄 : 親水公園の利用実热と評価に関寸る研究一東京都 23 区に㧍ける親水公園の現況と利用状況一、日本建築学会計画系論文集、第 462 号、 pp. 127-135、1994.8

13 練馬区区有通路・公共滶渠路線網圆、1997

14 和光市水路㗉定路線網図、作成年不明

15 緑と水の総合計画一板橋 500,000 人のグリーンクラブー調查編、公共渆渠調查、東 京都公園協会、1986.2

16 西東京市道路網图、西東京市、2003.3

17 ぜンリン住宅地図、ぜンリン、2001.4

18 ねりま䄭いの森、練馬区、2001

19 西東京市生産緑地地区指定図、西東京市、2003.3

20 東京都都市計画生産粶地地区図、綀馬区、2001.8

21 和光市都市計画生産緑地地区図、和光市、1998

22 板橋区都市計画図、板橋区、2003

23 建師省河川砂防技術基制（案）同解説 計画編、山海堂、p. 19、1976.6

24 土木学会糡：水理公式集、丸善、p. 360、1999.11

25 防災調節池等技術基淮(案)、社団法人、日本河川協会、p. 72、1977.11

26 建設省河川局都市河川室監修: 流域貯留施設等技術指針(案)、日本河川協会、1986.10

27 文部科学省国立天文台編: 理科年表平成 16 年度版、丸善、2003.11

28 松浦茂樹: 水辺空間の魅力と創造、鹿島出版会、pp. 77-78、1987.12

(2004年 5 月 7 日原稿受理，2004年 8 月 12 日採用決定） 